\title{
Współczesna grzeczność językowa w świadomości poznańskich kleryków
}

\section{Contemporary language politeness in the awareness of clerics from Poznań}

\author{
Anna Piotrowicz \\ Wydział Filologii Polskiej i Klasycznej, Uniwersytet im. Adama Mickiewicza w Poznaniu, \\ ul. Fredry 10, 61-701 Poznań, Polska; \\ e-mail: ape@amu.edu.pl

\section{Małgorzata Witaszek-Samborska} \\ Wydział Filologii Polskiej i Klasycznej, Uniwersytet im. Adama Mickiewicza w Poznaniu, \\ ul. Fredry 10, 61-701 Poznań, Polska; \\ e-mail: msamborska@tlen.pl
}

\begin{abstract}
Abstrakt
Na podstawie badania ankietowego przeprowadzonego w grupie 100 kleryków z dwu poznańskich seminariów Autorki artykułu próbują zrekonstruować świadomość językową młodych osób duchownych w zakresie grzecznościowych zwyczajów językowych. Z odpowiedzi wynika, że zdecydowana większość kleryków postrzega grzeczność językową jako działanie nastawione na interpretację (tak indywidualną, jak i społeczną), dobrze rozumie jej wagę w komunikacji, za rażące uważa zarówno brak grzeczności, jak i grzeczność przesadną, sztuczną. Niektórzy ankietowani używają przy tym leksyki związanej z religią (np. bliźni, brat, chrześcijański), wskazują też swego rodzaju przymus grzecznościowy - konieczność respektowania zasad poprawności politycznej. Klerycy dostrzegają różnice między grzecznością językową w swoich kontaktach z rówieśnikami a z osobami starszymi zwłaszcza w większym dystansie w stosunku do starszych. Poza wiekiem uwzględniają oni, choć rzadziej, zależność od środowiska, wychowania, poziomu dojrzałości.
\end{abstract}

Słowa kluczowe: grzeczność językowa; zmiany w komunikacji; kultura komunikacji.

\begin{abstract}
Based on a questionnaire survey conducted in a group of 100 students from the two Poznań seminaries, the authors of the article are trying to reconstruct the language awareness of young clergy in the field of polite linguistic habits. The responses show that for the vast majority of clerics language politeness is perceived as an action focused on interpretation (as an individual and socially), that they well understand its importance for communication, that they consider both a lack of politeness and exaggerated, artificial politeness as improper. Some respondents use the vocabulary associated with religion (e.g. bliźni, brat, chrześcijański), and they also indicate a kind of compulsion to be polite the need to respect the rules of political correctness. Clerics recognize the differences between the politeness of language in their dealings with their peers and with older people, especially with the
\end{abstract}


larger distance in relation to the elderly. In addition, they take into account, although less frequently, age, dependence on the environment, education, level of maturity.

Keywords: language politeness; changes in communication; communication culture.

O współczesnej grzeczności językowej w świadomości studentów polonistyki miałyśmy okazję pisać w kilku artykułach (Piotrowicz, Witaszek-Samborska 2014a; 2014b; 2015a). Obfitość spostrzeżeń i wątków poruszonych przez młodzież akademicką w odpowiedziach udzielanych podczas badania ankietowego stanowiącego podstawę źródłową analizowanego wówczas materiału skłoniła nas do powtórzenia owego badania w środowisku kleryków jako grupy społecznej, która powinna być szczególnie wrażliwa na wszelkie przejawy etykiety językowej (i, oczywiście, brak takich przejawów).

Ankieta przeprowadzona wśród 100 kleryków z Arcybiskupiego Seminarium Duchownego w Poznaniu i Wyższego Seminarium Duchownego Towarzystwa Chrystusowego dla Polonii Zagranicznej ${ }^{1}$ składała się z pięciu otwartych pytań: 1) Co według Ciebie oznacza pojęcie ,grzeczność językowa”?; 2) Co Cię razi w językowych zachowaniach grzecznościowych? U kogo? W jakich sytuacjach?; 3) Czy dostrzegasz różnice między grzecznością językową w swoich kontaktach z rówieśnikami a z osobami starszymi? Jeśli tak, określ, na czym polegają, i podaj przykłady; 4) Czy według Ciebie kontakty ludzi świeckich z osobami duchownymi różnią się pod względem grzeczności językowej od pozostałych kontaktów?; 5) Czy według Ciebie można mówić o specyfice grzecznościowych zachowań językowych w środowisku osób duchownych?

I tym razem uzyskałyśmy bardzo bogaty materiał, którego analiza i interpretacja przekraczały ramy jednego artykułu. Sądy kleryków o istnieniu bądź nie specyfiki językowych zachowań grzecznościowych w środowisku osób duchownych oraz etykiety językowej osób świeckich wobec księży, czyli odpowiedzi udzielone na pytania 4. i 5. ankiety, uczyniłyśmy przedmiotem rozważań w referacie wygłoszonym podczas konferencji „Język - Religia - Tożsamość” w Głogowie w marcu 2014 roku (Piotrowicz, Witaszek-Samborska 2015b). W niniejszym artykule omówimy odpowiedzi na pozostałe 3 pytania.

Zanim przystąpimy do analizy zgromadzonego materiału, przypomnijmy klasyczną już dziś definicję grzeczności językowej sformułowaną przez Małgorzatę Marcjanik:

Etykieta (czyli grzeczność) językowa to zbiór przyjętych w danej społeczności wzorów językowych zachowań grzecznościowych, zwyczajowo przyporządkowanych określonym sytuacjom pragmatycznym, takim jak spotkanie znajomej osoby, wyświadczenie nam przez kogoś przysługi, sprawienie komuś przykrości czy odniesienie przez kogoś sukcesu. Wskazane sytuacje wymagają takich zachowań, jak: powitanie

${ }^{1}$ W tym miejscu serdecznie dziękujemy Księżom Rektorom Pawłowi Wygralakowi i Andrzejowi Łysemu za wyrażenie zgody na nasze badanie ankietowe, a ks. Łukaszowi Glazerowi za jego przeprowadzenie. 
(np. Dzień dobry, Cześć, Hej), podziękowanie (np. Dziękuję bardzo, Dzięki, Jesteś wspaniała!), przeproszenie (np. Przepraszam, Nie gniewaj się, Tak mi przykro...), gratulacje (np. Gratuluję, Proszę przyjąć nasze gratulacje, Cieszę się!). [...]

Tak więc grzeczność językowa jest zjawiskiem wieloaspektowym, podlegającym społecznemu wartościowaniu, stanowiącym ważny składnik komunikacji. Ze względu na strukturę grzeczność można porównać do układu nerwowego, znajdującego się w różnych częściach ludzkiego organizmu.

Grzeczność „wpleciona” jest w każdą niemal wypowiedź językową kierowaną przez konkretną osobę do konkretnej osoby (bądź konkretnych osób, określonych nawet tylko zakresowo, tak jak grupa docelowa w mediach czy target w reklamie). Komunikując się, zmuszeni jesteśmy do wyboru któregoś z wariantów formalnojęzykowych grzeczności (2007: 12-13).

Warto też przytoczyć za Kazimierzem Ożogiem definicję modelu grzeczności językowej. Przez pojęcie to autor rozumie:

[...] system społecznie zaaprobowanych i powszechnie przyjętych w danej społeczności (grupie, wspólnocie) zasad, norm, określający pewien usankcjonowany sposób zachowania, także i werbalnego członków tej społeczności w kontaktach między sobą. Współcześnie jest to sposób zachowania określony jako odpowiedni, kulturalny, grzeczny, uprzejmy (por. połączenie typu: Zachowat się odpowiednio, kulturalnie, grzecznie, uprzejmie), i stoi w wyraźnej opozycji do zachowania nieodpowiedniego, niegrzecznego, nieuprzejmego (por. Jego zachowanie było nieodpowiednie, niekulturalne, niegrzeczne, nieuprzejme) (2007: 79).

Analizę odpowiedzi na pytanie 1. Co wedtug Ciebie oznacza pojęcie ,grzeczność językowa”? rozpoczniemy od przytoczenia ogólnych definicji wskazanego pojęcia, jakie próbowali sformułować klerycy²:

- Grzeczność językowa to sposób odnoszenia się do ludzi zgodnie z zasadami kultury i powszechnie przyjętymi dobrymi obyczajami.

- Stosowanie się do ogólnie przyjętych norm wyrażania się.

- Kulturalne zwracanie się do innych, wyrażanie swoich opinii w sposób kulturalny.

- Grzeczność językowa to kulturalne zwracanie się do innych.

- Posługiwanie się językiem w sposób życzliwy i odpowiedni wg norm językowych przyjętych powszechnie.

Jeden respondent zaprzeczył istnieniu pojęcia grzeczność językowa, pisząc: „Takie pojęcie nie istnieje, istnieje kultura języka (językowa). Grzecznym można być w zachowaniu, w sposobie bycia”.

2 Odpowiedzi na pytania ankietowe przytaczamy w niezmienionym kształcie leksykalno-składniowym, z korektą usterek interpunkcyjnych i - rzadkich - ortograficznych. 
W bardziej szczegółowych odpowiedziach kleryków, podobnie jak w materiale pozyskanym od studentów polonistyki, wskazać można trzy rysujące się kręgi zagadnień, które wyodrębniamy poniżej.

\section{Relacje nadawczo-odbiorcze}

Podkreślano tu zwłaszcza etyczny wymiar komunikacji, szacunek w stosunku do interlokutorów:

- Jest to dbanie o kulturę języka. Wynika ona po części z dobrego nastawienia do drugiego człowieka, z otwartości na ludzi i chęci nawiązania z nimi rozmowy, jak również z umiejętności panowania nad swoim językiem. Ten szacunek dla drugiego człowieka to chrześcijańska miłość do bliźniego.

- Grzeczność językowa nie tylko wyraża się w kwestii lingwistycznej i stylistycznej, lecz także życzliwość komunikowanych treści. Grzeczność powinna wyrażać także otwartość i brak jakiejkolwiek ironii czy szyderstwa.

- Grzeczność językowa to wg mnie wyrażanie się do drugiej osoby z grzecznością oraz szacunkiem.

- Pojęcie to związane jest z wzajemnym szacunkiem i uprzejmością.

- Pewien takt w rozmowie i życzliwość w stosunku do rozmówcy oraz przestrzeganie zasad savoir vivre'u.

- Stosowanie słów, które nie powodują u słuchacza/adresata poczucia braku szacunku.

- Jest to taktowne rozmawianie, bez wyliczania błędów i niedoskonałości osoby, z którą dialogujemy.

- Jest to odnoszenie się do drugiej osoby w sposób życzliwy, bez zbędnych złośliwości. Grzeczność językowa wyraża to, co jest we wnętrzu człowieka i pokazuje, kim tak naprawdę jestem.

- Sposób posługiwania się językiem w taki sposób, by nie obrażać rozmówcy.

- Mówienie w taki sposób, aby drugi nie poczuł się urażony, poniżony.

- Kultura osobista, odpowiednie wyrażanie się stosunku do bliźnich.

- Odpowiednia kultura języka - powinno się wiedzieć, jak należy zwracać się do konkretnych osób.

- Uprzejme zwracanie się do siebie, wszystko co związane z kulturą języka, wypowiedzi.

- Wyrażenia nacechowane uprzejmością.

- Pojęcie to oznacza kulturalne zwracanie się do siebie, unikając obrażania się, dwuznacznych wypowiedzi i prymitywnych odzywek.

- Użycie słów i składni, które nie obrażają interlokutora.

- Brakiem grzeczności językowej jest według mnie zagadywanie tak, iż druga strona nie ma nic do powiedzenia albo nie ma możliwości dojść do głosu. 
Uwzględnienie etycznego aspektu grzeczności językowej zdaniem niektórych kleryków skutkuje mówieniem oględnym, nie wprost:

- Pojęcie to kojarzy mi się z używaniem w wypowiedziach wyrażeń „okrągłych”, tzn. niebezpośrednich, zamiast opisywania rzeczywistości tak, jak ją się widzi, używa się określeń zawoalowanych, aby uniknąć wywołania poczucia dyskomfortu w rozmówcy lub wykazania swojej kultury językowej (np. przez używanie wyrażeń „Z wyższej półki” itp.).

- Wg mnie jest to takie powiedzenie „że się kogoś nie lubi” w taki sposób, że używa się słów i wyrazów, które brzmią ładnie i które wprost nie obrażają drugiej osoby.

W jednej odpowiedzi powiązano grzeczność językową z tematem wypowiedzi i jego skutkami: „To mowa pozbawiona wulgaryzmów i powierzchownej tematyki, bo taka tematyka często kończy się szyderstwem i plotkarstwem”.

Tylko raz podkreślono umiejętność słuchania rozmówcy: „Grzeczność językowa polega także na stosowaniu się do powszechnych zasad obowiązujących w dyskusji, np. słuchanie rozmówcy i umożliwianie mu swobodnej wypowiedzi”. Dodajmy, że we wspomnianych na wstępie artykułu ankietach studenckich na ten element grzeczności zwracano uwagę znacznie częściej.

W niektórych ankietach - przypuszczalnie ze względu na świadomość społecznej roli księży - dodatkowo wspominano o swego rodzaju przymusach grzecznościowych, jakimi są dostosowywanie się do zasad poprawności politycznej oraz do reguł obowiązujących w sytuacjach oficjalnych:

- Zwykła uprzejmość, dyplomacja, ale czasem też i poprawność polityczna czy wazeliniarstwo.

- Nieobgadywanie, niekłamanie, także poprawność polityczna.

- Taki dobór słów, wyrażeń, składni etc., by pokazać rozmówcy, że go szanujemy, mamy dobre intencje itp., lub też by zachować wymaganą formalność.

Zwracano uwagę na konieczność dostosowania wypowiedzi do możliwości percepcyjnych odbiorcy:

- Kulturalne zwracanie się do odbiorcy i używanie adekwatnych słów, tak, aby rozmówca był w stanie je zrozumieć.

- Wypowiedź z założeniem i staraniem dostosowania do poziomu rozmówcy.

- Odpowiednie dopasowywanie słów do poziomu rozmowy.

- Używanie słów i pojęć odpowiednich wobec innych osób.

- Dostosowanie rejestru słów do konkretnego środowiska słuchaczy. 


\section{Sytuacja komunikacyjna}

Czasem uwzględniano okoliczności kontaktu werbalnego:

- Według mnie grzeczność językowa to zasady etykiety językowej, które mówią, jak w różnych sytuacjach należy zwracać się do innych ludzi.

- To dostosowanie stylu wypowiedzi do sytuacji (formalny/potoczny).

- Umiejętne i stosowne do sytuacji dobieranie słów i zwrotów.

- Ton odpowiedni do sytuacji rozmowy (nie za głośno, za cicho czy agresywnie).

- Dostosowanie odpowiednie językowe do danej sytuacji.

- Panowanie nad swoim językiem, używając słów odpowiednich do towarzystwa: „Milczenie jest złotem, a mówienie srebrem” bądź „Lepiej milczeć niż głupstwo powiedzieć”.

Niekiedy podkreślano rolę czynników emocjonalnych wpływających na kształt językowej grzeczności:

- Używanie słów uznawanych za poprawne, stosowane w kontaktach oficjalnych, stonowanych emocjonalnie i wyważonych.

- Powściągliwość, ekonomia słowa w sytuacjach napięcia emocjonalnego.

\section{Kod językowy}

Grzeczność językową utożsamiano z poprawnością językową:

- Moim zdaniem oznacza to używanie poprawnego języka, poprawnych sformułowań.

- Jest to szczególna dbałość o poprawność językową.

- Dbanie o poprawną polszczyznę.

- Język, w którym są zdania złożone, poprawnie akcentowane.

Uwzględniano też konieczność stosowania formuł etykietalnych:

- Według mnie owe stwierdzenie oznacza kulturalne posługiwanie się językiem, a więc wypowiadanie grzecznościowych zwrotów itp.

- Używanie sformułowań „dziękuję, proszę, przepraszam”.

- Używanie wobec drugiej osoby słów, które powszechnie uznaje się za „magiczne": przepraszam, proszę, dziękuję.

- Używanie odpowiednich zwrotów grzecznościowych.

- Zazwyczaj odnosi się do zwrotów powitalnych, podziękowań, przeprosin.

Zwracano uwagę na konieczność nieużywania słów zbyt ekspresywnych

- Prowadzenie rozmowy dwóch kulturalnych ludzi bez używania ekspresywnych słów i zdań. 
oraz wulgarnych i obraźliwych:

- Grzeczność językowa oznacza unikanie wulgaryzmów.

- Kulturalne wypowiadanie się, bez wulgaryzmów.

- Grzeczność językowa to przede wszystkim kulturalne wysławianie się, unikanie wulgaryzmów.

- Grzeczność językowa polega na posługiwaniu się mową, w której nie ma wulgaryzmów.

- Nieużywanie słów potocznych, wulgarnych, dwuznacznych itp.

- Używanie zwrotów i wyrażanie się z kulturą językową, bez wulgaryzmów.

- Zachowanie pewnego stylu wypowiadania się z unikaniem wulgaryzmów.

- Brak wyzwisk, wulgaryzmów i przekleństw.

- Wyrażać się bez używania wulgaryzmów.

- Brak używania wulgaryzmów.

Raz podkreślono też ogólnie wagę estetyki komunikacji:

- Język ładny, prosty, przystępny.

Dwu kleryków zaakcentowało nieco inny aspekt grzeczności językowej efekt perlokucyjny pozwalający na „zachowanie własnej twarzy” (Goffman 2000):

- Używanie w rozmowie zwrotów, które mają na celu zdobycie szacunku czy sympatii danej osoby.

- Przesadne przymilanie się, chwalenie.

Na pytanie 2.: Co Cię razi w językowych zachowaniach grzecznościowych? U kogo? W jakich sytuacjach? kilka osób (3) odpowiedziało krótko, negatywnie: „Nic”. „U nikogo”. Jeden z kleryków napisał: ,jeśli występują zachowania grzecznościowe, to sama radość i nic nie razi”.

Znacznie częściej jednak klerycy wskazywali różne negatywne zjawiska skrajne zresztą: od braku grzeczności po grzeczność przesadną i wyrafinowaną. W dwu odpowiedziach zwrócono uwagę na obie te skrajności:

- Z jednej strony upadek zachowań grzecznościowych wśród niektórych środowisk, $\mathrm{z}$ drugiej strony przesadne używanie form grzecznościowych w sposób fałszywy, mający na celu podlizywanie się.

- Razi mnie z jednej strony zbytnia przesadność językowa, z drugiej zaś wulgaryzmy, szczególnie u młodzieży i dzieci.

W licznych odpowiedziach powrócił wątek wulgaryzacji polszczyzny, co pomijamy tu, gdyż na wymóg nieużywania wulgaryzmów klerycy zwracali uwagę już przy pytaniu pierwszym.

Inne rażące cechy uchybiające grzeczności językowej, wskazywane przez respondentów, to przede wszystkim:

a) przesada i sztuczność w zachowaniach grzecznościowych: 
- Sztuczność i pokrywanie grzecznością rzeczywistych uczuć, czasem też niepotrzebny dystans i formalizm. Szczególnie irytujące pośród osób bliskich, rodziny itp., gdy mówią to, co ma brzmieć grzecznie, zamiast szczerze. Celują w tym procederze kobiety z nadmierną grzecznością jako ironią.

- Denerwuje mnie pewna sztuczność.

- Sztuczność, wyuczenie, aktorstwo.

- Rażąca jest sztuczność, gdy rozmówca sili się na używanie wyrażeń i zwrotów, które uważa za mądre lub jedynie akceptowalne przez adresata. Sytuacja ta ma często miejsce w rozmowach podwładny - przełożony (zwłaszcza w strukturze zhierarchizowanej), a także w spotkaniu osób różnych „klas” - tzn. robotnik - ,inteligent”.

- Czasem razi mnie sztuczność w zachowywaniu poprawności językowej.

- W językowych zachowaniach grzecznościowych razi mnie to, gdy są używane na wyrost i przesadnie.

- Razi mnie nadużywanie grzeczności językowej, budujące dziwny dystans.

- Razi mnie, gdy są one przekoloryzowane, grzeczność językowa potrzebuje naturalności, a jest taka, gdy na co dzień aplikujemy ją do naszego życia.

- Zbytnia przesadniość, wyczuwalna sztuczność i silenie się na zachowanie poprawności języka.

- Nadmierne używanie tytułów naukowych związanych z funkcją wobec osób, które niejednokrotnie tego sobie nie życzą.

- Czasem razi mnie przesadny formalizm, brak wyrażania pozytywnych emocji, pomimo dbałości o zwroty grzecznościowe (proszę, dzień dobry, szanowny panie, proszę pana), inaczej mówiąc - „oschłość” rozmówcy.

- Przesadne i uparte próby bycia uprzejmym, np. przy posiłkach.

- Pewna przesada grzecznościowa, szczególnie u rówieśników.

- Zbyt częste ich używanie w mało adekwatnych sytuacjach.

Zwracano także uwagę na czynniki pozawerbalne:

- gestykulację,

- głupi uśmiech, złośliwość w oczach.

b) instrumentalne wykorzystywanie zachowań grzecznościowych:

- Razi mnie fałszywość, sztuczność w zachowywaniu się - myśli się jedno, a robi się drugie. Dzieje się to w sytuacjach podbramkowych i ważnych dla osób zależnych od kogoś. Widać to u nauczycieli do dyrekcji czy prezesa w firmie.

- Razi mnie wyczuwalna dwulicowość i chęć „podlizywania się” podwładnych swoim przełożonym. Najczęściej pojawia się to w celu złagodzenia odpowiedzialności za popełniony czyn bądź w celu uzyskania dla siebie czegoś.

- Nieszczerość! Kiedy to, co się mówi, nie jest od serca. Służalczość, podlizywanie się. 
- Nieszczerość, patos, wyszukane egzaltacyjne słowa u osób, które w ten sposób pragną coś osiągnąć - jakąś korzyść dla siebie, bądź po prostu udają.

- Fałsz, zbytnia nachalność. Dotyczy to zwłaszcza tych, którzy mają o sobie wysokie mniemanie. Widać to, kiedy ta osoba coś chce.

- Jest to takie podlizywanie się osobom wpływowym.

- Tzw. wazeliniarstwo czy też przesadne akcentowanie zwrotów typu „Szczęść Boże”.

- Na pewno razi mnie przesadna grzeczność, wręcz przymilanie się i „tanie” schlebianie rozmówcy.

- Razi mnie przesadna grzeczność, szczególnie u osób czujących się podporządkowanymi w stosunku do mnie.

- Zbytnie cukierkowanie, przysładzanie.

- Razi mnie zbyt przesłodzona grzeczność.

- Razi mnie używanie zmiękczeń i zdrobnień, niekiedy na siłę w stosunku do rozmówcy, na którym zależy temu, kto aktualnie się zwraca. Ma to miejsce w przypadku interesantów, którzy chcą załatwić coś polubownie. Jest to częsty przypadek w biurze parafialnym.

c) grzeczność protekcjonalna:

- Nadmierna uprzejmość, wywyższanie się po to, by innych pod pozorami grzeczności poniżyć.

d) językowe przejawy stanów emocjonalnych utrudniających komunikację:

- Znudzenie, widoczna niechęć wyrażana w słowach.

- Za szybka rozmowa, za nerwowa rozmowa.

e) naruszanie tabu językowego:

- Zbyt mocne wchodzenie w sprawy osobiste.

f) niski rejestr leksykalno-stylistyczny i niestaranność językowa:

- Nadmierne używanie kolokwializmów i zdrobnień słów.

- Głównie u młodzieży, kiedy odzywają się do osób starszych slangiem, np. „dobra” zamiast „dobrze”.

- Niewyraźna mowa, np. połykanie ostatnich sylab (czasem) u księdza podczas mszy świętej.

- Głupie odzywki (nie na miejscu) u młodszych rozmówców.

g) zanikanie formuł grzecznościowych:

- U dzieci razi mnie niezwracanie się do rodziców słowami „mamo” i „tato”.

- Nieumiejętność stosowania zwrotów, które przynależą do takiej mowy.

h) zbyt wysoki rejestr leksykalno-stylistyczny: 
- Za bardzo wymowne „ą i ę" (choć, oczywiście nie wiadomo, czy respondent nie miał na myśli hiperpoprawnej wymowy samogłosek nosowych).

- Zbytnia patetyczność.

- Patos i przeintelektualizowanie.

Za całkowity brak grzeczności uznano:

- brak cierpliwości w słuchaniu i mówieniu,

- agresywność,

- chamstwo i prostactwo w każdej sytuacji,

- obłudę, brak autentyczności,

- pogardę i poniżanie,

- ignorowanie rozmówcy.

Pytanie 3., przypomnijmy, brzmiało: Czy dostrzegasz różnice między grzecznościa językowa w swoich kontaktach z rówieśnikami a z osobami starszymi? Jeśli tak, określ, na czym polegaja, i podaj przykłady.

Kilkunastu (11) respondentów takich różnic nie wskazało. Jeden z nich szczególnie głęboko uzasadnił swą odpowiedź:

- Z szacunku do każdego jako do człowieka, bez względu na wiek, rozmawiam także $\mathrm{z}$ rówieśnikami i z osobami młodszymi z pełnią szacunku, chcąc by także młodsi zdolni to przyjąć czuli, że są traktowani poważnie, „jak dorośli”, z pełnią szacunku... by budować, a nie deptać.

Inny z kolei surowo ocenił brak zachowań grzecznościowych osób starszych, pisząc:

- Zasadniczo nie zauważam różnicy, może jedynie taką, że osoby starsze z góry zyskują pewien szacunek i autorytet ze względu na wiek. Jednakże, bywa to czasem zwodnicze i pozorne, gdyż okazuje się wielokrotnie, że osoby starsze myślą, że im się należy grzeczność i szacunek, a same pozostają oschłe i ordynarne.

Wielu kleryków różnicę pokoleniową wiązało z wynikającą z wieku różnicą więzi między interlokutorami. Ich zdaniem kontakty z rówieśnikami sprzyjają szybkiemu nawiązywaniu mniej formalnych więzi, zaś w relacjach z osobami starszymi zachowany zostaje większy dystans. W ankietach czytamy:

- Różnice nie są wielkie, ponieważ pamiętam, że każdy jest osobą. Starszym oddaje się szacunek ze względu na ich wiek, doświadczenie; rówieśnikom daje się odnieść wrażenie, że są szanowani w sposób normalny, nie wydziwiając.

- Łatwiej mi zachować kulturę języka w kontaktach ze starszymi, ponieważ oni zwracają na to uwagę i dbają o nią. Z młodymi trudniej kulturalnie rozmawiać. 
- Grzeczność w kontaktach z rówieśnikami polega na nieużywaniu słów wulgarnych. Jest to jednak grzeczność „luźniejsza” od grzeczności językowej w stosunku do osób starszych, które to kontakty wymagają więcej szacunku i respektu.

- Wobec młodszych grzeczność ta jest inna, bardziej luźna, zaś wobec starszych trzeba dawkować dobór słów.

- Tak, występują różnice. $Z$ rówieśnikami jesteśmy na tym samym poziomie relacji. Jeżeli chodzi o osoby starsze, grzeczność językowa wynika z większego doświadczenia życiowego tych osób, często też z respektu, jaki budzi taka osoba, która jest dla mnie przykładem.

- Do osób starszych odnoszę się uprzejmiej i grzeczniej.

- Do rówieśników zdarza zwracać się luźno. Do starszych zazwyczaj język jest bardziej oficjalny.

- Kontakty z rówieśnikami zazwyczaj mniej grzecznościowe, łatwiej odformalizowujące się.

- Różnice wynikają z różnicy wieku. Ze starszymi wymaga się większej kultury.

Kilka osób zwróciło uwagę na zależność między grzecznością a innymi czynnikami niż wiek:

- Moim zdaniem obecnie nie tyle zależy to od wieku, co od środowiska, z którego ktoś się wywodzi - jak został wychowany itp.

- To zależy od dojrzałości każdej pojedynczej osoby.

- Zależy od kontekstu i wychowania danej grupy społecznej.

Podawano też przykłady środków językowo-stylistycznych różniących oba typy kontaktów:

- Odnośnie osób starszych nie używam kolokwializmów, skrótów myślowych, „ksywek”, a takiej „etykiety” nie zachowuję odnośnie rówieśników.

- Owszem, dostrzegam różnice. $Z$ rówieśnikami mogę sobie pozwolić na grę słowną $\mathrm{i}$ będzie to odpowiednio odebrane, $\mathrm{z}$ osobami starszymi nie powinienem tak żartować, bez znajomości kontekstu.

- Do rówieśników bardziej używa się slangu, zwrotów poufałych, czasem dwuznacznych, ale z sympatią.

- Z rówieśnikami mogę pożartować sobie i wprowadzam „lekki” język.

- Tak, dostrzegam takie różnice, ponieważ z rówieśnikami można porozmawiać „na luzie”, używając zwrotów młodzieżowych, natomiast ze starszymi rozmawiam poważniej.

- Różnica polega na większej otwartości i stosowaniu bardziej potocznego słownictwa w stosunku do rówieśników.

- W kontaktach z osobami starszymi widzę większą kontrolę wypowiadanych słów, są one często inne, „dostosowane” do ich wieku. Wynika to z szacunku do osób starszych. 
- Rozmowy ze starszymi są zwykle nacechowane większą życzliwością, wyraźniejszą wymową, spokojną wypowiedzią. Wynika to z szacunku.

- Wiadomo, że gdy rozmawiam z rówieśnikiem, mój język jest bardziej prosty i codzienny. Jednak gdy podejmuję rozmowę z osobą starszą i to jeszcze taką, którą nie znam zbyt dobrze, używam bardziej „wyszukanych” słów.

- Osoby starsze bardziej zwracają uwagę na słuchacza i potrafią krytycznie odpowiadać, budując dialog. Młodzi często stosują dwuosobowy monolog pozbawiony kultury, a co dopiero grzeczności.

- Ewentualnie inne słownictwo.

Różnic w grzeczności wewnątrz- i międzypokoleniowej upatrywano też w repertuarze wykorzystywanych formuł grzecznościowych (bądź ich braku):

- Różnice te polegają na stosowaniu do osób starszych zwrotów grzecznościowych, np. „Proszę Pana”.

- Osobom starszym okazuję należny im szacunek, zwracam się do nich per „Pan”.

- Dostrzegam różnice, a polegają one na zwracaniu się do starszych przez „Pan” i „Pani”.

- Do osób starszych zwracam się formą „pan”, „pani”, natomiast do rówieśników „ty”.

- Różne rodzaje zwrotów, np. „Cześć, jak się masz” vs „Dzień dobry”. Do starszych używane „Pan, Pani”. Czasem do obcych rówieśników.

- W stosunku do rówieśników rozmowa jest bardziej żywiołowa, spontaniczna i bezpośrednia, nie używa się raczej wiele zwrotów grzecznościowych. W stosunku do osób starszych czuje się więcej szacunku, bardziej czuwa nad językiem, by nie urazić. Chociażby inaczej złożę życzenia urodzinowe koledze niż dziadkowi.

- Słowa używane do osób starszych są bardziej oficjalne, np. zamiast „siema” - „dzień dobry”.

- Stosuje się inne zwroty, np. w kontaktach z rówieśnikami „ok, dzięki”, a w kontaktach z osobami starszymi - „w porządku, dziękuję”.

Wnioski wynikające z zaprezentowanej powyżej analizy odpowiedzi udzielonych w ankiecie przez kleryków można sformułować w następujący sposób. Studenci seminariów duchownych, podobnie jak studenci poznańskiej polonistyki, mają świadomość istnienia grzeczności językowej jako zjawiska wieloaspektowego, wykraczającego poza poprawność językową, a mieszczącego się w szeroko rozumianych normach zachowań społecznych. W zakresie relacji nadawczo-odbiorczych podkreślają przede wszystkim etyczny wymiar grzeczności, wyrażającej szacunek dla interlokutora. Z rzadka pojawia się tu w odpowiedziach leksyka związana z religią - bliźni, brat, chrześcijański itp., nieobecna w ankietach polonistów. Drugą cechą różniącą wypowiedzi przedstawicieli tych dwu środowisk jest wskazywanie na swego rodzaju przymus grzecznościowy - konieczność re- 
spektowania zasad poprawności politycznej - o czym piszą tylko klerycy. Z kolei ujmowanie grzeczności językowej z perspektywy odbiorcy, przejawiające się w dbałości o uważne wysłuchanie nadawcy, częściej pojawiało się w ankietach przyszłych filologów, a incydentalnie wśród przyszłych księży. Klerycy zwracają też uwagę na poprawność i estetykę wypowiedzi oraz - z rzadka - na sytuacyjne uwarunkowania językowej etykiety.

We współczesnych zachowaniach językowych rażą respondentów zwłaszcza przesada i sztuczność, przejawiające się w stosowaniu zbyt wysokiego rejestru leksykalno-stylistycznego, a często motywowane instrumentalnym wykorzystywaniem owych zachowań. Z drugiej strony razi, oczywiście, brak grzeczności i zbyt niski rejestr używanych środków.

Różnic między grzecznością językową w swoich kontaktach z rówieśnikami a z osobami starszymi upatrują klerycy zwłaszcza w większym dystansie w stosunku do tych ostatnich. Poza wiekiem uwzględniają tu, choć rzadziej, zależność od środowiska, wychowania, poziomu dojrzałości.

Materiał uzyskany z badania ankietowego, którym objęłyśmy dotąd dwa środowiska studenckie (polonistów i kleryków), jest bogaty i dość zróżnicowany. Wskazuje to na wagę zjawiska zwanego grzecznościa językowa w świadomości młodego pokolenia Polaków.

\section{Bibliografia}

Goffman E., 2000, Człowiek w teatrze życia codziennego (The Presentation of Self in Everyday Life, 1959), opracował i słowem wstępnym poprzedził J. Szacki, przeł. H. Danter-Śpiewak i P. Śpiewak, Warszawa.

Marcjanik M., 2007, Grzeczność w komunikacji językowej, Warszawa.

Ożóg K., 2007, Uwagi o wspótczesnej polskiej grzeczności językowej, w: K. Ożóg, Polszczyzna przełomu XX i XXI wieku. Wybrane zagadnienia, Rzeszów, s. 77-88.

Piotrowicz A., Witaszek-Samborska M., 2014a, Grzeczność językowa w świadomości studentów polonistyki, w: Grzeczność nie jest nauka tatwa ani mała. Język, działanie, kultura, red. J. Bloch, D. Lewandowska-Jaros, R. Pawelec, Warszawa, s. 269-277.

Piotrowicz A., Witaszek-Samborska M., 2014b, Międzypokoleniowe różnice w grzeczności językowej w opinii studentów polonistyki, „Słowo. Studia językoznawcze”, nr 5, s. $192-200$.

Piotrowicz A., Witaszek-Samborska M., 2015a, Co razi studentów polonistyki w języowych zachowaniach grzecznościowych Polaków?, „Roczniki Humanistyczne”, z. 6, s. 181-192.

Piotrowicz A., Witaszek-Samborska M., 2015b, Co sadza poznańscy klerycy o językowych zachowaniach grzecznościowych swojego środowiska i wobec niego?, w: Język. Religia. Tożsamość, t. 11: Język tożsamości, red. G. Cyran, E. Skorupska-Raczyńska, Gorzów Wielkopolski, s. 123-134. 
